\title{
Bukti Penghakiman Allah yang Adil di dalam 2 Tesalonika 1:3-10 Menurut Pendekatan Analisis Wacana
}

\section{Evidence of God's Righteous Judgment in 2 Thessalonians 1:3-10 According to Discourse Analysis Approach}

\author{
Alexander Darmawan Limasaputra \\ Program Studi Magister Teologi Sekolah Tinggi Teologi Amanat Agung, Jakarta \\ Korespondensi: alexander.darmawan@gmail.com
}

\begin{abstract}
Abstrak: Tema mengenai penghakiman Allah yang adil merupakan tema yang penting di dalam 2 Tesalonika 1. Tema ini memiliki keterkaitan dengan keadaan jemaat Tesalonika yang saat itu sedang terusmenerus mengalami penganiayaan. Makalah ini akan memaparkan bagaimana Paulus mengembangkan tema penghakiman Allah yang adil di 2 Tesalonika 1:3-10 dengan menggunakan pendekatan analisis wacana. Makalah ini akan menjelaskan bahwa Allah yang adil akan menghakimi setiap orang yaitu dengan memberikan hukuman kepada para penindas dan upah kepada orang percaya. Analisis wacana digunakan di dalam makalah ini karena merupakan pendekatan yang dapat memberikan landasan yang lebih kuat ketika menganalisis suatu teks dan menyediakan kriteria objektif ketika menyelidiki masalah suatu teks. Tujuan dari makalah ini adalah mendorong orang percaya untuk memiliki penghiburan dan kekuatan ketika mengalami penganiayaan karena Allah yang adil akan menghakimi setiap manusia.
\end{abstract}

Kata-kata kunci: Allah yang Adil, Penghakiman, Penganiayaan, Pembalasan, Upah, Analisis Wacana

Abstract: The theme of the righteous judgment of God is an important theme in 2 Thessalonians 1. This theme has a connection with the situation of the Thessalonians who were currently undergoing persecution. This paper will explain how Paul developed the theme of God's righteous judgment in 2 Thessalonians 1:3-10 by using the discourse analysis approach. This paper will explain that a righteous God will judge everyone by punishing the oppressors and rewarding the believers. Discourse analysis is used in this paper because it is an approach that can provide a stronger foundation when analyzing a text and provides objective criteria when investigating the problem of a text. The purpose of this paper is to encourage believers to have comfort and strength when experiencing persecution because a righteous God will judge every human being.

Keywords: Righteous God, Judgment, Persecution, Retribution, Reward, Discourse analysis 


\section{PENDAHULUAN}

Tema mengenai penghakiman Allah yang adil merupakan tema yang penting di dalam 2 Tesalonika $1 .{ }^{1}$ Keberadaan tema ini memiliki keterkaitan dengan keadaan jemaat Tesalonika yang saat itu sedang mengalami penganiayaan yang terus menerus dari pada penindas. ${ }^{2}$ Untuk itu Paulus segera menuliskan tema ini di bagian awal suratnya yaitu di

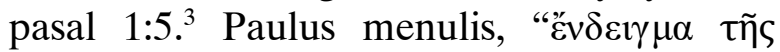

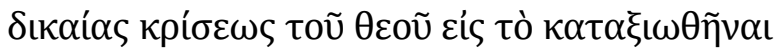

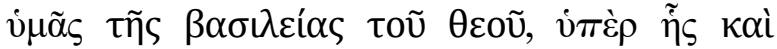
$\pi \alpha ́ \sigma \chi \varepsilon \tau \varepsilon "$ (Suatu bukti dari penghakiman Allah yang adil supaya kalian dianggap layak bagi kerajaan Allah yang karenanya kalian juga menderita). ${ }^{4}$

Tujuan Paulus menuliskan tema penghakiman Allah yang adil adalah untuk menjelaskan bahwa Allah itu adil dan Ia akan menghakimi dengan memberikan hukuman kepada para penindas dan upah kepada orang percaya. Penghakiman Allah yang adil ini akan terjadi di masa depan ketika Yesus Kristus datang untuk kedua kali.

${ }^{1}$ Karl P. Donfried dan I. Howard Marshall, The Theology of the Shorter Pauline Letters (Cambridge: Cambridge University Press, 1993), 90.

${ }^{2}$ Gordon D. Fee, The First and Second Letters to the Thessalonians, NICNT (Grand Rapids: Eerdmans, 2009), 252-253; Paul Ellingworth dan Eugene A. Nida, SuratSurat Paulus Kepada Jemaat di Tesalonika, terj. Kareasi H. Tambur dan Anwar Tjen, Pedoman Penafsiran Alkitab (Jakarta: LAI, 2001), 94.

${ }^{3}$ Penulis berpendapat 2 Tesalonika ditulis oleh Paulus, meski demikian terdapat beberapa sarjana Perjanjian Baru yang meragukan hal ini. Secara umum sarjana yang meragukan kepenulisan Paulus didasarkan kepada kosakata, gaya penulisan atau isi teologi yang berbeda dengan surat-surat Paulus yang dianggap asli. Untuk diskusi lebih lanjut dapat dilihat di Raymond E. Brown, An Introduction to the New Testament (New York: Doubleday, 1997), 592-96; Donald Guthrie, New Testament Introduction, ed. ke-4 (Downers Grove: InterVarsity, 1990), 592-99; D.A. Carson dan Douglas J. Moo, An Introduction to the New Testament, ed. ke-2 (Grand Rapids: Zondervan, 2005), 536-42.

${ }^{4}$ Terjemahan bahasa Indonesia dari Yunani di dalam makalah ini adalah terjemahan dari penulis sendiri.
Berdasarkan penjelasan di atas maka makalah ini akan berupaya menjawab pertanyaan: bagaimanakah Paulus mengembangkan tema penghakiman Allah yang adil di dalam perikop 2 Tesalonika 1:3-10? Untuk itu makalah ini akan memaparkan bagaimana Paulus mengembangkan tema penghakiman Allah yang adil di dalam perikop 2 Tesalonika 1:3-10 menurut pendekatan analisis wacana. ${ }^{5}$

Pendekatan AW digunakan di dalam makalah ini karena AW memberikan landasan yang lebih kuat ketika menganalisis suatu teks dan menyediakan kriteria objektif yang dapat digunakan dalam menyelidiki masalah suatu teks. Untuk itu pendekatan AW memiliki kelebihan daripada pendekatan eksegesis tradisional yang sering mengandalkan wawasan intuitif dari penafsirnya. ${ }^{6}$

\section{PENGERTIAN ANALISIS WACANA}

Untuk dapat memahami AW di 2 Tesalonika 1:3-10 maka makalah ini akan terlebih dahulu memaparkan secara singkat pengertian AW. Stephen H. Levinsohn mendefinisikan AW sebagai berikut,

Discourse analysis is an analysis of language features that draws its explanations, not from within the sentence or word (i.e., the factors involved are not syntactic or

\footnotetext{
${ }^{5}$ Analisis wacana di dalam bahasa Inggris dikenal dengan istilah discourse analysis. Selanjutnya analisis wacana akan disingkat menjadi AW. Perikop 2 Tesalonika 1:3-10 di dalam makalah ini didasarkan kepada pembagian struktur yang dilakukan oleh Gordon D. Fee yang membagi 2 Tesalonika 1 ke dalam tiga bagian yaitu salam (ay. 1-2), ucapan syukur dan penghakiman Allah (ay. 310), dan doa (ay. 11-12) (Fee, Thessalonians, 243). Untuk pembagian struktur pasal 1 yang mirip dengan Fee dapat dilihat juga di F.F. Bruce, 1 and 2 Thessalonians, WBC 45 (Dallas: Word, 2002), 139; D. Michael Martin, 1, 2 Thessalonians, NAC 33 (Nashville: Broadman \& Holman, 1995), 44; Leon Morris, 1 and 2 Thessalonians, vol. 13, TNTC (Downers Grove: InterVarsity, 1984), 113.

${ }^{6}$ Constantine R. Campbell, Advances in the Study of Greek (Grand Rapids: Zondervan, 2015), 149.
} 
morphological), but extrasententially (from the linguistic and wider context). ${ }^{7}$

Definisi dari Levinsohn di atas menjelaskan bahwa AW merupakan pendekatan yang berguna untuk mempelajari bagian teks yang lebih luas daripada kalimat yaitu hubungan antar kalimat atau yang lebih besar seperti perikop, paragraf dan teks secara keseluruhan. Definisi ini menjelaskan juga bahwa AW memiliki kesamaan dengan analisis sastra dan analisis retoris, untuk itu pendekatan AW tidak berusaha untuk mengganti pendekatan yang telah ada tetapi melengkapinya. Namun demikian, kontribusi yang paling khas dari AW adalah sifat linguistik yang kuat. AW umumnya bergerak dari tata bahasa dan sintaksis sebuah teks ke masalah teks yang lebih besar daripada memulainya dari gambaran besar. ${ }^{8}$

Terdapat empat aliran ${ }^{9}$ utama dari pendekatan AW yaitu pertama, aliran Amerika

${ }^{7}$ Stephen H. Levinsohn, Discourse Features of New Testament Greek, ed. ke-2 (Dallas: SIL International, 2000), viii. Lihat juga definisi yang diberikan oleh Constantine R. Campbell, "Discourse analysis is an interdisciplinary approach to understanding how units of text relate to one another in order to create the theme, message, and structure of a text" (Campbell, Advances in the Study of Greek, 148-49).

${ }^{8}$ Campbell, Advances in the Study of Greek, 149.

${ }^{9}$ Tentu saja terdapat kelemahan dari masing-masing aliran. Aliran dari Inggris dan Australia dinilai lemah karena membutuhkan pemikiran ulang tentang bagaimana bahasa dipandang di dalam Perjanjian Baru termasuk bagaimana wacana didefinisikan, dipikirkan dan bagaimana fenomena teks dinilai sebagai data di dalam analisis. Aliran Eropa Kontinental dinilai lemah karena begitu banyak pendekatan interdisipliner yang perlu diperhatikan dan dimasukkan di dalam kerangka kerjanya. Aliran ini juga perlu memperhatikan berbagai aspek secara independen dan bagaimanakah berbagai aspek ini dapat dibentuk dengan tepat. Aliran dari Afrika Selatan dinilai memiliki kelemahan karena dalam pembentukan struktur diagram dinilai terlalu subjektif dan tidak ada metodologi yang jelas untuk menyelesaikan permasalahan ini. Lebih lanjut mengenai perbedaan dan penilaian dari empat aliran ini dapat dilihat di Stanley E. Porter, "Discourse Analysis and New Testament Studies: An Introductory Survey," dalam Discourse Analysis and Other Topics in Biblical Greek, ed. oleh Stanley E. Porter dan D.A. Carson, JSNTS 113 (Sheffield: Sheffield Academic, 1995), 24-35; Campbell, Advances in the Study of Greek,
Utara yang dikembangkan oleh Summer Institute of Linguistics (SIL). Para sarjana yang berada di SIL adalah Levinsohn dan Steven E. Runge. Karena aliran Amerika Utara merupakan pendekatan yang akan dipakai di dalam makalah ini maka penjelasan dari aliran Amerika Utara akan dijelaskan kemudian. Kedua, aliran Inggris dan Australia yang dikembangkan oleh M.A.K. Halliday dan R. Hasan. Bagi aliran ini, bahasa dipandang sebagai semiotik sosial yang terdiri dari berbagai jaringan sistem yaitu kelompokkelompok yang saling terhubung dan yang membentuk komponen-komponen bahasa. Fokus dari aliran ini adalah kohesi yaitu mengacu kepada cara di mana suatu teks dapat bersatu. Kohesi juga merujuk kepada relasi makna yang ada di dalam suatu teks dan yang mendefinisikan teks tersebut. Untuk itu masalah mendasar dari AW adalah bagaimana pembaca dapat memahami suatu wacana dengan koheren. Ketiga, aliran Eropa Kontinental yang dikembangkan oleh D. Hellholm, W. Schenk dan B.C. Johanson. AW dari aliran ini adalah yang paling tidak kohesif, yang paling luas jangkauannya dan berfokus kepada retorik. AW di dalam aliran ini berkontribusi kepada minat dan terminologi dalam membahas struktur makro daripada struktur mikro yang membentuk superstruktur. Hasilnya adalah pembagian ke dalam diskusi mengenai sintaksis, semantik dan pragmatik. Keempat, aliran Afrika Selatan yang dikembangkan oleh J.P. Louw. Louw mengembangkan metode colon analysis di mana suatu teks dianalisis dan dipecah ke dalam constituent cola. Sebuah colon adalah sebuah unit yang terbentuk di sekitar struktur nominatif dan predikatif. Constituent cola ini pertama-tama diisolasi dan keterkaitan cola-cola tersebut digambarkan ke dalam bentuk diagram sehingga mendemonstrasikan hubungan antara unit terkecil dari

150-52. Lihat juga M.A.K. Halliday, An Introduction to Functional Grammar (London: Edwin Arnold, 1995); Johannes P. Louw, Semantics of New Testament Greek (Philadelphia: Fortress, 1982). 
kola dan unit semantik yang lebih besar, dengan demikian akan ada hubungan teori antara bentuk dan makna yang melampaui colon sebagai satuan makna yang terkecil.

Penjelasan di makalah ini secara khusus mengambil pendekatan dari aliran Amerika Utara yang dikembangkan oleh Levinsohn dan Runge. Hal ini disebabkan karena pertama, Summer Institute of Linguistics sebagai penganut AW aliran Amerika Utara sudah ahli dalam pekerjaan menerjemahkan Alkitab. Kedua, aliran ini memiliki pendekatan fungsional yang bekerja berdasarkan prinsip level dan lapisan bahasa, dimulai dari bagian terkecil bahasa hingga struktur yang semakin besar sehingga pendekatan ini menghasilkan analisis informatif wacana yang lengkap. ${ }^{10}$ Ketiga, pendekatan dari aliran ini melengkapi pendekatan-pendekatan yang sudah ada dan menghindarkan pembaca dari jebakan yaitu pembaca begitu terpikat dengan penjelasan teks sehingga gagal untuk menganalisis aturan sintaksis atau semantik dan pembaca tidak menghubungkan teks dengan aturan sintaksis atau semantik. ${ }^{11}$

Runge dan Levinsohn menjelaskan bahwa pendekatan AW yang dianutnya adalah pendekatan fungsional. ${ }^{12}$ Levinsohn dengan mengutip Robert A. Dooley mendefinisikan pendekatan fungsional sebagai, "an attempt to discover and describe what linguistic structures are used for: for functions they serve, the factors that condition their use." 13

\footnotetext{
${ }^{10}$ Porter, "Discourse Analysis and New Testament Studies," 24-26.

${ }^{11}$ Steven E. Runge, Discourse Grammar of the Greek New Testament (Peabody: Hendrickson, 2010), 4-5. Perhatikan juga kritik dari Stanley E. Porter yang berkata bahwa pendekatan dari SIL dapat sangat terfokus kepada tata bahasa kalimat dan studi tentang fenomena linguistik sehingga kurang memperhatikan analisis tingkat kalimat dan keseluruhan teks di dalam satu kitab dan keseluruhan Alkitab (Porter, "Discourse Analysis and New Testament Studies," 26-27).

${ }^{12}$ Levinsohn, Discourse Features, vii; Runge, Discourse Grammar, 3.

${ }^{13}$ Levinsohn, Discourse Features, vii.
}

Runge menjelaskan tiga prinsip dasar yang menjadi panduan dalam pendekatan AW yaitu pertama, "choice implies meaning." Ini artinya penulis membuat pilihan ketika ia mengomunikasikan tulisannya. Pilihan-pilihan ini diarahkan oleh suatu tujuan dan sasaran komunikasi serta berimplikasi kepada makna yang terkait dengan pilihan tersebut. Untuk itu pilihan penulis dalam menggunakan atau tidak menggunakan pilihan tertentu akan memberi wawasan yang signifikan mengenai makna suatu teks. Kedua, semantic meaning versus pragmatic effect. Ini artinya sangat penting bagi pembaca untuk dapat membedakan antara makna yang melekat pada sesuatu dan efek yang dicapai dengan menggunakannya dalam konteks tertentu. Ketiga, default versus marked framework. Salah satu aspek dari AW adalah mengorganisasi pilihan yang tersedia ke dalam sistem yang terorganisasi. Untuk itu pembaca perlu mempertimbangkan apakah suatu teks berada di dalam posisi standar atau tertanda. ${ }^{14}$

\section{ANALISIS WACANA 2 TESALONIKA 1:3-10}

Untuk memperjelas AW maka pertamatama akan dipaparkan tabel kerja 2 Tesalonika 1:3-10 berdasarkan penggunaan partikel konjungsi.

Dari tabel kerja ini dapat diperhatikan bahwa 2 Tesalonika 1:3-10 terdiri dari 2 bagian utama, yaitu ayat 3-4 dan 5-10. Adanya dua bagian ini didasarkan atas keberadaan asindeton yang berada di ayat $3 \mathrm{a}$ dan $5 \mathrm{a} .{ }^{15}$ Berikut ini akan dipaparkan penjelasan dua bagian tersebut.

\footnotetext{
${ }^{14}$ Runge, Discourse Grammar, 5-11.

${ }^{15}$ Asindeton menunjuk kepada penghubungan klausa atau komponen klausa tanpa menggunakan kata penghubung. Lihat penjelasan lebih lanjut mengenai asindeton di halaman-halaman selanjutnya.
} 
Tabel 1 Lembar Kerja 2 Tesalonika 1:3-10

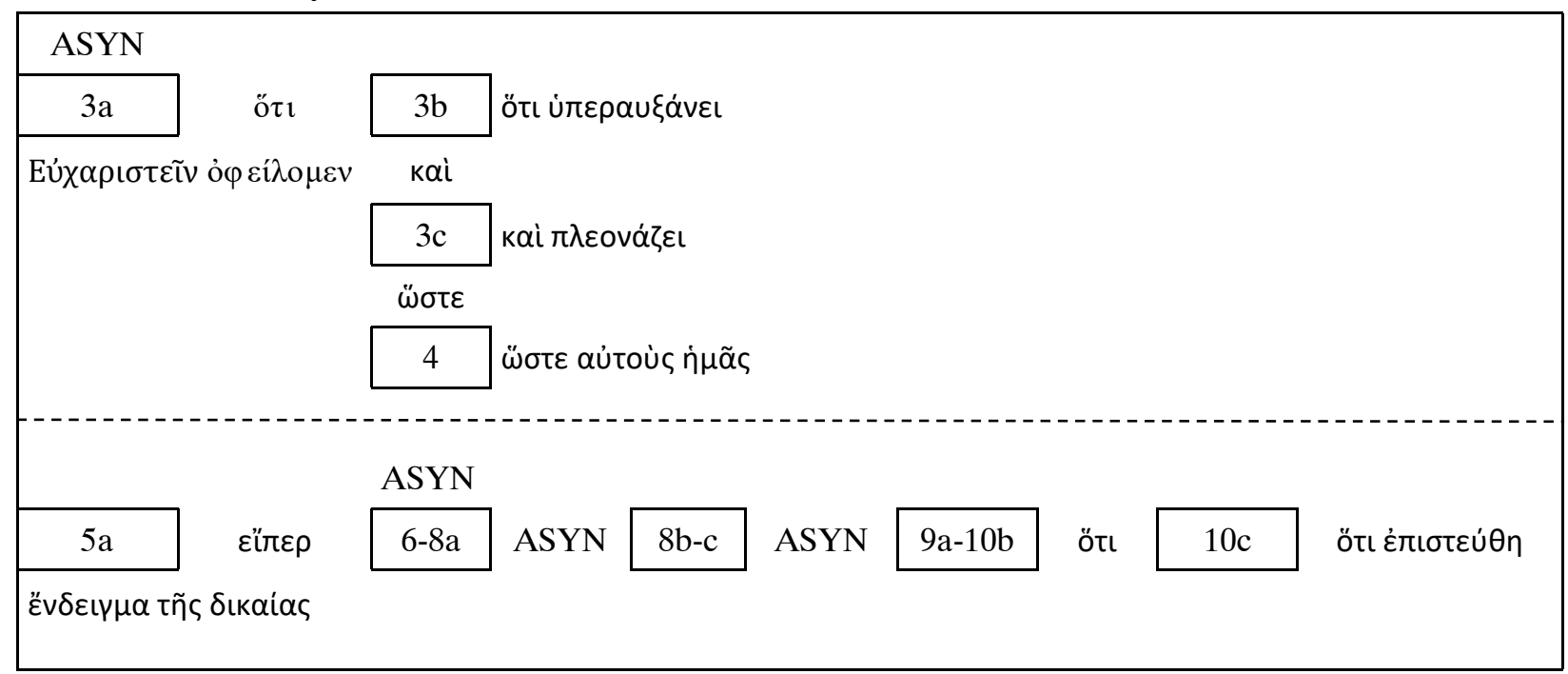

\section{Bagian Pertama (ay. 3-4)}

Dalam ayat 3-4 Paulus berkata,

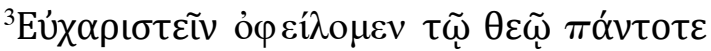

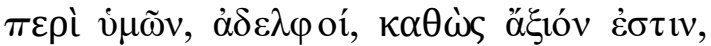

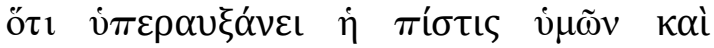

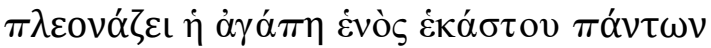

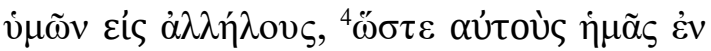

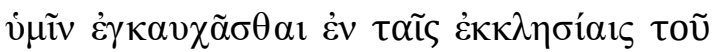

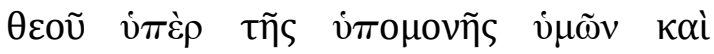

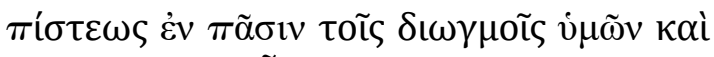

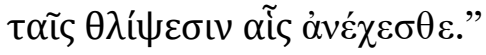

Terjemahan bahasa Indonesia dari ayat 3-4 adalah sebagai berikut,

${ }^{3}$ Kami harus bersyukur kepada Allah setiap waktu mengenai kalian, saudarasaudara, sebagaimana ini adalah benar, karena iman kalian sedang bertumbuh besar dan kasih setiap kalian telah berkembang satu sama lain, ${ }^{4}$ sehingga kami sendiri bermegah tentang kalian di antara jemaat-jemaat Allah mengenai ketabahan dan iman kalian di dalam semua penganiayaan-penganiayaan dan di dalam penindasan-penindasan yang kalian tanggung.
Bagian pertama ini berisi ucapan syukur Paulus kepada jemaat Tesalonika karena mereka tetap memiliki ketabahan dan iman di dalam penganiayaan dan penindasan yang sedang mereka alami. Karena ketabahan dan iman inilah maka Paulus memegahkan jemaat Tesalonika di antara jemaat Allah yang lain.

Di dalam perikop ini terdapat fitur-fitur wacana yang perlu diperhatikan. ${ }^{16}$ Fitur wacana yang pertama adalah asindeton. Asindeton menunjuk kepada penghubungan klausa atau komponen klausa tanpa menggunakan kata penghubung. Asindeton digunakan ketika penulis merasa tidak perlu untuk membuat hubungan yang spesifik dan eksplisit antar klausa yang ingin ditandakan. Asindeton ditemukan dalam beberapa kondisi yaitu pertama, asindeton ditemukan pada titik diskontinuitas seperti pada awal pemikiran atau topik baru. Kedua, asindeton ditemukan di mana hubungan antara klausa sudah cukup jelas atau dalam konteks hubungan yang dekat

${ }^{16}$ Fitur wacana dapat juga diistilahkan dengan istilah partikel penyambung. Partikel penyambung memainkan peran fungsional dengan menunjukkan bagaimana penulis bermaksud untuk menghubungkan satu klausa dengan yang lain berdasarkan partikel penyambung yang digunakan (Runge, Discourse Grammar, 18). 
dan memberi petunjuk adanya hubungan proposisi dari generik ke spesifik, di mana proposisi kedua memberi contoh spesifik dari proposisi generik yang mendahuluinya. ${ }^{17}$

Di dalam bagian ini asindeton terdapat di ayat 3a. Keberadaan asindeton menjadi petunjuk adanya topik baru di ayat 3 . Dari konteks dapat diperhatikan bahwa ayat 1-2 berbicara mengenai salam Paulus kepada jemaat Tesalonika, sedangkan ayat 3-4 berbicara mengenai ucapan syukur Paulus.

Fitur wacana yang kedua adalah Paulus

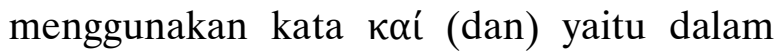

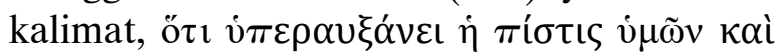

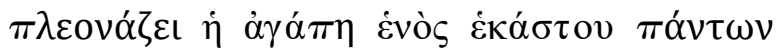

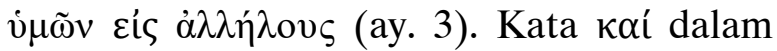
kalimat ini menjelaskan adanya kelanjutan dan korelasi antara iman yang sedang bertumbuh dan kasih yang berkembang dari jemaat Tesalonika.

Fitur wacana yang ketiga adalah frame of reference. Frame of references mengacu kepada penempatan informasi ke dalam posisi yang ditandai sehingga menghasilkan kerangka referensi yang eksplisit untuk menghubungkan apa yang mengikuti dengan apa yang terjadi sebelumnya. ${ }^{18}$ Levinsohn mengistilahkan frame of reference dengan istilah point of departure. Levinsohn berkata bahwa point of departure menunjuk kepada elemen yang ditempatkan di awal klausa atau kalimat dengan dua fungsi ganda yaitu memberikan titik awal dalam berkomunikasi dan mengaitkan secara kohesif klausa-klausa berikutnya kepada sesuatu yang sudah ada di dalam konteks misalnya dengan sesuatu yang dapat diakses oleh representasi mental pendengar. ${ }^{19}$

Frame of reference dapat diketahui ketika sebuah kata yang berada di awal kalimat

\footnotetext{
${ }^{17}$ Runge, Discourse Grammar, 20-23; Levinsohn, Discourse Features, 118-20.

${ }^{18}$ Runge, Discourse Grammar, 194.

${ }^{19}$ Levinsohn, Discourse Features, 8.
}

melanggar aliran informasi yang alami. Dalam bahasa Yunani koine, kalimat yang sesuai dengan aliran informasi yang alami akan diawali dengan kata kerja. Urutan katanya adalah sebagai berikut, kata kerja + subjek + objek + keterangan, sedangkan kalimat yang menyimpang dari aliran informasi yang alami tidak diawali dengan kata kerja. $^{20}$

Di ayat 4 terdapat frame of reference, yaitu di awal ayat 4 terdapat kata $̋ \sigma \tau \varepsilon$ yang merupakan konjungsi dan yang kemudian diikuti

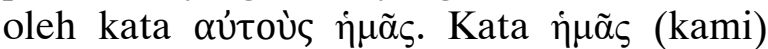
berbentuk pronomina, persona, akusatif, jamak sehingga menyimpang dari aliran infor-

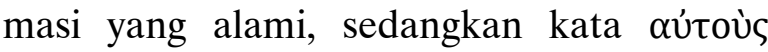
(sendiri) dalam ayat ini berfungsi untuk mengintensifkan atau menekankan kata $\dot{\eta} \mu \tilde{\alpha} \varsigma .{ }^{21}$ Berdasarkan hal ini kata $\dot{\eta} \mu \tilde{\alpha} \varsigma$ merupakan frame of reference yang merujuk kepada Paulus, Silwanus dan Timotius yang sudah ditulis di ayat 1 .

\section{Bagian Kedua (ay. 5-10)}

\section{Ayat 5-10 berkata,}

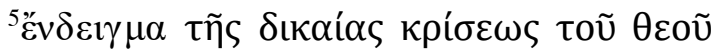

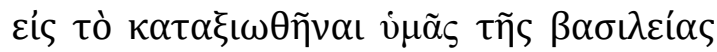

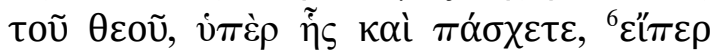

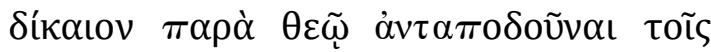

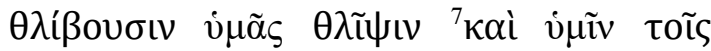

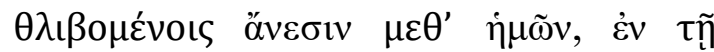

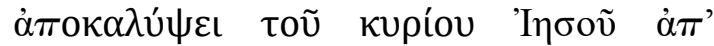

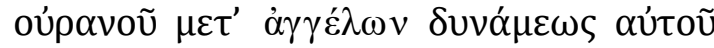

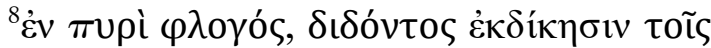

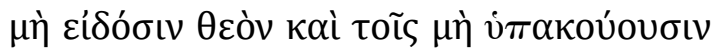

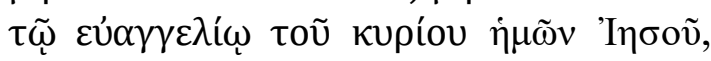

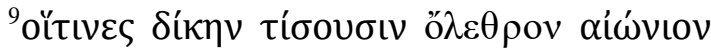

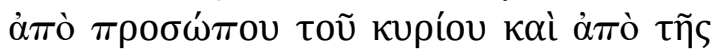

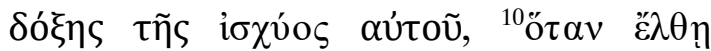

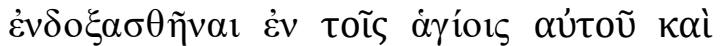

${ }^{20} \mathrm{BDF}, \S 472$; Ibid., 45.

${ }^{21}$ William D. Mounce, Basics of Biblical Greek Grammar, ed. ke-4 (Grand Rapids: Zondervan, 2019), 124; Daniel B. Wallace, Greek Grammar Beyond the Basics (Grand Rapids: Zondervan, 1996), 349. 


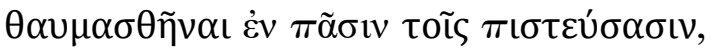

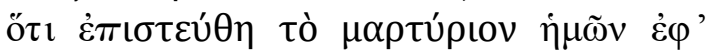

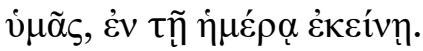

Terjemahan bahasa Indonesia dari ayat 5-10 adalah sebagai berikut,

${ }^{5}$ Suatu bukti dari penghakiman Allah yang adil supaya kalian dianggap layak bagi kerajaan Allah yang karenanya kalian juga menderita, ${ }^{6}$ jika adil menurut Allah untuk membalaskan kepada orangorang yang menindas kalian dengan penindasan ${ }^{7}$ dan kepada kalian yang ditindas dengan kelegaan bersama kami pada saat penampakan Tuhan Yesus dari surga bersama malaikat-malaikatNya yang berkuasa ${ }^{8}$ dalam api yang menyala-nyala, memberikan pembalasan kepada orang-orang yang tidak mengenal Allah dan kepada orang-orang yang tidak taat kepada berita Injil Tuhan kita Yesus, ${ }^{9}$ mereka akan menerima hukuman yaitu kehancuran kekal, jauh dari kehadiran Allah dan jauh dari kemuliaan kekuatan-Nya, ${ }^{10}$ apabila Dia datang pada hari itu untuk dimuliakan di antara orang-orang kudus-Nya dan untuk diagungkan di antara semua orang-orang percaya sebab kesaksian kami yang kami bawa kepadamu telah dipercaya.

Di dalam bagian kedua ini terdapat fiturfitur wacana. Fitur wacanayang pertama adalah asindeton. Asindeton di bagian ini terdapat di ayat 5a, 8b dan 9a. Keberadaan asindeton di ayat 5a memberi petunjuk adanya titik diskontinuitas yaitu adanya pemikiran atau topik baru. Hal ini dapat diperhatikan dari konteks ayat 3-4 yang berbicara mengenai ucapan syukur Paulus, sedangkan ayat 5-10 berbicara mengenai dua aspek penghakiman Allah yang adil yaitu pembalasan kepada orang yang tidak percaya dan upah bagi orang percaya.

Keberadaan asindeton di ayat $8 \mathrm{~b}$ memberi petunjuk adanya hubungan proposisi dari generik ke spesifik, di mana proposisi kedua memberi contoh spesifik dari proposisi generik yang mendahuluinya. ${ }^{22}$ Dari konteks ayat dapat diperhatikan bahwa proposisi spesifik yang ingin dijelaskan adalah pembalasan Allah yang terdapat di ayat 5a-8a diberikan juga kepada orang-orang yang tidak mengenal Allah dan kepada orangorang yang tidak taat kepada berita Injil (ay. $8 b-c)$.

Keberadaan asindeton di ayat 9a memberi petunjuk adanya hubungan proposisi dari generik ke spesifik. Dari konteks ayat dapat diperhatikan bahwa proposisi spesifik yang ingin dijelaskan adalah orang yang tidak mengenal Allah dan yang tidak taat kepada berita Injil yang terdapat di ayat 8b-c akan menerima hukuman pada hari Tuhan yaitu berupa kehancuran kekal, jauh dari kehadiran Allah dan jauh dari kemuliaan-Nya, sedangkan orang yang bersikap sebaliknya yaitu jemaat Tesalonika yang mau menerima berita Injil akan menerima kemuliaan dan diagungkan (9a). Hal ini akan terjadi ketika Kristus datang untuk kedua kalinya (ay. 10).

Adanya hubungan proposisi dari generik ke spesifik di ayat 5 sampai ayat 10 membuat ayat 5-10 memiliki keterkaitan yang sangat dekat dan menjadi satu bagian besar yang

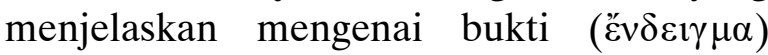
penghakiman Allah yang adil. Hubungan ini juga memberi penjelasan bahwa हैv $\delta \varepsilon 1 \gamma \mu \alpha$ tidak berkorelasi dengan ayat 3-4.

Fitur wacanayang kedua adalah overspecification. Overspecification merupakan feature pragmatika yang bertujuan untuk memperjelas pesan penulis dan mengacu kepada penambahan informasi yang lebih banyak daripada yang dibutuhkan. Tujuannya untuk mengidentifikasi informasi dengan lebih jelas, contohnya mengidentifikasi siapa melakukan apa kepada siapa dengan lebih jelas. Penambahan informasi ini seringkali dimuat secara tematis dan terhubung dengan tema

${ }^{22}$ Levinsohn, Discourse Features, 120. 
konteks tertentu. ${ }^{23}$ Dalam bagian ini overspe-

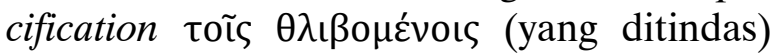
merupakan overspecification dan memberi informasi yang lebih jelas mengenai $\dot{v} \mu \mathrm{i} v$ (kalian) (ay. 7). ${ }^{24}$

Fitur wacanayang ketiga adalah right dislocation. Right dislocation merupakan penempatan informasi yang ditambahkan di akhir klausa yang menjelaskan klausa yang disebutkan sebelumnya. ${ }^{25}$ Dalam bagian ini yang merupakan right dislocation adalah kalimat

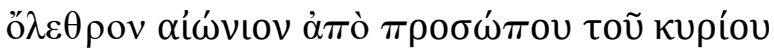

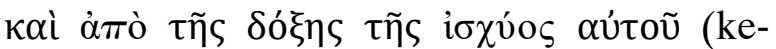
hancuran kekal, jauh dari kehadiran Allah dan jauh dari kemuliaan kekuatan-Nya) (ay. 9). Kalimat ini menjelaskan kalimat yang

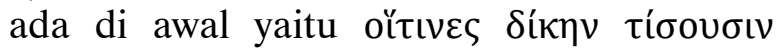
(mereka akan menerima pembalasan). ${ }^{26}$

Fitur wacanayang keempat adalah emphasis. Emphasis mengacu kepada penempatan informasi baru yang dinyatakan di dalam posisi yang ditandai dan memiliki efek menekankan. Fungsi dari emphasis adalah untuk menarik perhatian pembaca. ${ }^{27}$ Dalam bagian ini yang menjadi emphasis adalah

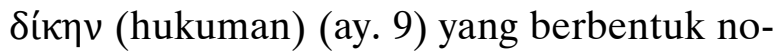
mina, akusatif, feminin, tunggal. ${ }^{28}$

Cara untuk mengenali apakah suatu kata merupakan emphasis sama dengan cara mengenali suatu kata merupakan frame of reference. Emphasis dapat diketahui ketika sebuah kata yang berada di awal kalimat melanggar aliran informasi yang alami. Dalam bahasa Yunani koine, kalimat yang sesuai dengan aliran informasi yang alami akan diawali dengan kata kerja. Urutan

\footnotetext{
${ }^{23}$ Runge, Discourse Grammar, 317, 388.

${ }^{24}$ Steven E. Runge, The Lexham Discourse Greek New Testament (Bellingham: Logos Research Systems, 2008), 2Tes. 1:7.

${ }^{25}$ Runge, Discourse Grammar, 317, 388-89. 1:9.

${ }^{26}$ Runge, The Lexham Discourse Greek, 2 Tesalonika

${ }^{27}$ Runge, Discourse Grammar, 190.

${ }^{28}$ Runge, The Lexham Discourse Greek, 2 Tesalonika
}

katanya adalah sebagai berikut, kata kerja + subjek + objek + keterangan, sedangkan kalimat yang menyimpang dari aliran informasi yang alami tidak diawali dengan kata kerja. $^{29}$

Fitur wacanayang kelima adalah near/far distinction. Near/far distinction digunakan dalam konteks tertentu untuk menghasilkan efek tertentu, terkhusus ketika perbedaan tempat atau ruang tidak hadir secara eksplisit. Near distinction menggunakan artikel oũ̃os (ini), sedangkan far distinction meng-

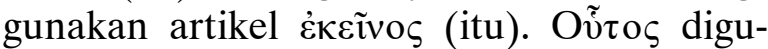
nakan untuk menandai rujukan sebagai tema yang sentral di dalam wacana, sedangkan $\dot{\varepsilon} \kappa \varepsilon i ̃ v o \zeta ~ m e n a n d a i$ rujukan sebagai tema yang tidak terlalu sentral di dalam wacana. ${ }^{30}$ Oṽ̃os juga digunakan untuk menarik perhatian kepada elemen-elemen yang dekat

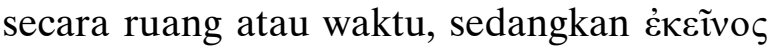
digunakan kepada elemen-elemen yang jauh secara ruang dan waktu dari konteks. ${ }^{31}$ Pada bagian ini terdapat far distinction yaitu

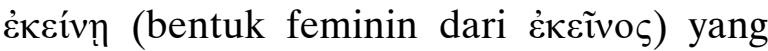
merujuk kepada hari yang akan terjadi di masa depan di mana Yesus datang untuk dimuliakan di antara orang-orang kudusNya dan diagungkan di antara semua orangorang percaya (ay. 10). ${ }^{32}$

Di bagian ini juga perlu diperhatikan adanya penanda yaitu $\varepsilon \| \pi \varepsilon \rho$ yang terdapat di ayat 6 . Artikel $\varepsilon " \pi \varepsilon \rho$ memiliki arti "if indeed, provided that." ${ }^{\prime 3}$ Keberadaan artikel $\varepsilon " \pi \tau \varepsilon \rho$ di bagian ini memperkenalkan adanya protasis dan apodosis di mana Paulus mengasumsikan suatu kebenaran dari apa yang sedang ditesiskan. ${ }^{34}$ Protasis ini terdapat dari ayat 6-

\footnotetext{
${ }^{29}$ Levinsohn, Discourse Features, 45; BDF, $\$ 472$.

${ }^{30}$ Runge, Discourse Grammar, 368-70, 389.

${ }^{31}$ Ibid., 383.

${ }^{32}$ Runge, The Lexham Discourse Greek, 2 Tesalonika $1: 10$.

${ }^{33}$ BDAG, s.v. “el";” BDF, §454.

${ }^{34}$ Wallace, Greek Grammar, 682-84; Abraham J. Malherbe, The Letters to the Thessalonians, AYB (New Haven: Yale, 2008), 396; Ben Witherington III, 1 and 2 Thessalonians (Grand Rapids: Eerdmans, 2006), 193.
} 
10 yang dimulai dengan kalimat $\varepsilon^{\prime \prime} \pi \varepsilon \rho$

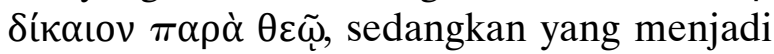

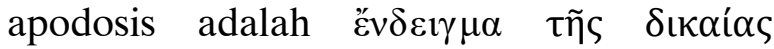

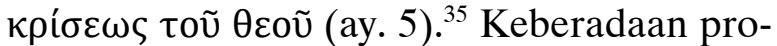
tasis dan apodosis membentuk kesatuan kalimat yang ada di ayat 5-10.

\section{PEMBAHASAN 2 TESALONIKA 1: 3-10}

Pembahasan di bawah ini akan mengikuti pemaparan AW yang telah dipaparkan di atas di mana perikop 2 Tesalonika 1:3-10 terdiri dari dua bagian. Bagian pertama adalah ayat 3-4 dan bagian kedua adalah ayat 5-10.

\section{Bagian Pertama (ay. 3-4)}

Bagian ini merupakan bagian yang menyatakan ucapan syukur Paulus yang terdiri dari dua hal, yaitu pernyataan ucapan syukur Paulus (ay. 3a) dan penyebab Paulus mengucap syukur (ay. 3b-c). Di dalam ayat 3a

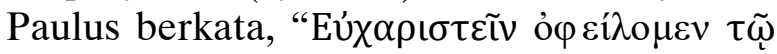

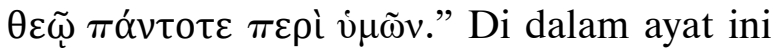
terdapat kata ó $\varphi \varepsilon i ́ \lambda o \mu \varepsilon v$, kata dasarnya adalah ỏ $\varphi \varepsilon i ́ \lambda \omega$ yang berarti wajib atau harus. ${ }^{36}$ Kata kerja ò $\varphi \varepsilon i ́ \lambda o \mu \varepsilon v$ memiliki aspek tindakan yang kontinu yang berarti ucapan syukur Paulus harus dilakukan secara terus menerus. ${ }^{37}$

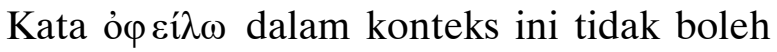
diartikan bahwa Paulus memandang ucapan syukur sebagai suatu tugas dan bukan suatu sukacita. Dalam konteks ini Paulus sebagai pendiri dari jemaat Tesalonika (1Tes. 2:7; Kis. 17:1-9) mengakui keharusannya untuk mengucap syukur kepada Allah karena Ia telah memberikan pertumbuhan iman dan kasih di dalam kehidupan jemaat Tesalonika. Bagi Paulus tanpa pertumbuhan iman yang diberikan Allah maka jemaat tidak dapat menanggung penganiayaan dan penin-

\footnotetext{
${ }^{35}$ Jeffrey A.D. Weima, 1-2 Thessalonians, BECNT (Grand Rapids: Baker Academic, 2014), 462, 464.

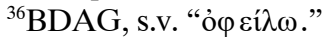

${ }^{37}$ Mounce, Basics of Biblical Greek, 165; Wallace, Greek Grammar, 514.
}

dasan yang terus menerus terjadi. Karena itu kata ỏ $\varphi \varepsilon i ́ \lambda \omega$ merupakan bentuk ekspresi Paulus bahwa ia sangat bersyukur kepada Allah. ${ }^{38}$

Di ayat 3b-c terdapat kata ö $\tau$ (karena) yang merupakan konjungsi kausal. Kata ini mengungkapkan dasar alasan dari suatu tindakan. ${ }^{39}$ Dalam hal ini Paulus menjelaskan dua alasan mengapa ia harus bersyukur kepada Allah, yaitu karena, "نं $\pi \varepsilon \rho \alpha v \xi \alpha ́ v \varepsilon \iota ~ \dot{\eta} \pi i ́ \sigma \tau \iota \varsigma$

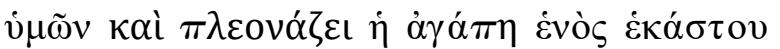

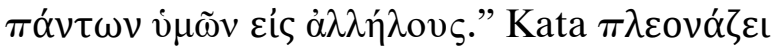
dan $\dot{v} \pi \varepsilon \rho \alpha u \xi \alpha ́ v \varepsilon \iota$ memiliki aspek tindakan yang kontinu dan bermakna bahwa Paulus harus terus menerus mengucap syukur kepada Allah, alasannya adalah karena iman jemaat terus menerus bertumbuh besar dan kasih jemaat terus menerus berkembang. ${ }^{40}$

Di ayat 4 terdapat frame of reference yaitu $\dot{\eta} \mu \tilde{\alpha} \varsigma$ yang memberi kerangka acuan antara keberadaan iman dan kasih jemaat dengan kemegahan Paulus, Silwanus dan Timotius. Di ayat 4 juga terdapat $̋ \sigma \tau \varepsilon$ (sehingga) yang diikuti oleh verba infinitif $(\dot{\varepsilon} \gamma \kappa \alpha v \chi \tilde{\alpha} \sigma \theta \alpha \imath)$ yang bermakna hasil. ${ }^{41}$ Hal ini berarti kemegahan Paulus, Silwanus dan Timotius di antara jemaat-jemaat Allah merupakan hasil dari iman dan kasih jemaat yang bertumbuh dan berkembang (ay. 4). ${ }^{42}$

Paulus kemudian melanjutkan alasan yang lebih tepat mengenai tindakannya yang bermegah di antara jemaat-jemaat Allah yaitu

${ }^{38}$ Weima, 1-2 Thessalonians, 448; Gene L. Green, The Letters to the Thessalonians, PNTC (Grand Rapids: Eerdmans, 2002), 279.

${ }^{39}$ Wallace, Greek Grammar, 674.

${ }^{40}$ Ibid., 514.

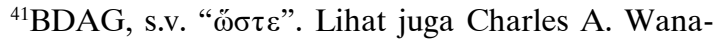
maker, The Epistles to the Thessalonians, NIGTC (Grand Rapids: Eerdmans, 1990), 217; Wallace, Greek Grammar, 592-93.

${ }^{42}$ Jemaat-jemaat Allah ini dapat menunjuk kepada jemaat-jemaat di wilayah Yerusalem, Yudea (1Tes. 2:14), Makedonia dan Akhaya (1Tes. 1:8), jemaat Korintus di mana Paulus menulis surat 2 Tesalonika, atau jemaat di mana Paulus memberitakan Injil (Weima, 1-2 Thessalonians, 455-56; Bruce, 1 and 2 Thessalonians, 145-46). 


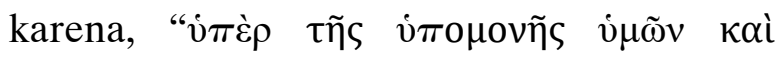

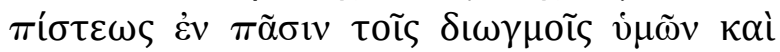

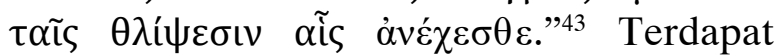
beberapa hal yang perlu diperhatikan dari

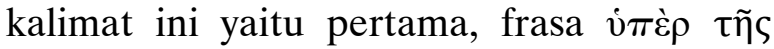

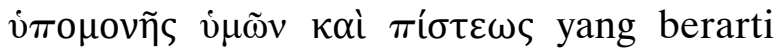
jemaat Tesalonika memiliki kesabaran, ketekunan, ketabahan dan kesetiaan. ${ }^{44}$

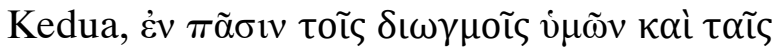
$\theta \lambda i ́ \psi \varepsilon \sigma \iota v$. Dalam frasa ini terdapat kata sifat $\pi \tilde{\alpha} \varsigma$ yang dilanjutkan oleh kata $\delta \iota \omega \gamma \mu o ́ s ~ d a n$ $\theta \lambda i ́ \psi \varepsilon \sigma \iota v$ yang berbentuk jamak yang bermakna penganiayaan dan penindasan tidak terjadi sekali tetapi terjadi beberapa kali. ${ }^{45}$ Dua kata ini ( $\delta \iota \omega \gamma \mu o ́ s ~ d a n ~ \theta \lambda i ́ \psi \varepsilon \sigma \iota v)$ memiliki koherensi yaitu berbicara mengenai penderitaan secara fisik, mental dan emosional dan berbicara mengenai penderitaan yang terjadi karena faktor agama. ${ }^{46}$ Koherensi ini memberi sebuah penggambaran mental di dalam benak pembaca. ${ }^{47}$

Ketiga, kata kerja $\alpha \dot{\alpha} \varepsilon \dot{\chi} \varepsilon \sigma \theta \varepsilon^{48}$ yang berbentuk kala sekarang, medium, indikatif dan memiliki arti penganiayaan serta penindasan tidak terjadi di masa lalu tetapi sedang

\footnotetext{
${ }^{43}$ Ernest Best, The First and Second Epistles to the Thessalonians, BNTC (Peabody: Hendrickson, 1972), 253; Wanamaker, Thessalonians, 218.

${ }^{44}$ BDAG, s.v. "نं $\pi 0 \mu$ ovท́”; Weima, 1-2 Thessalonians, 456.

${ }^{45}$ Kata sifat $\pi \tilde{\alpha} \sigma v$ yang diawali $\dot{\varepsilon} v$ yang memiliki arti di dalam semua hal (BDAG, s.v. " $\pi \tilde{\alpha} \varsigma ")$. Kata $\pi i ́ \sigma \tau \varepsilon \omega \varsigma$,

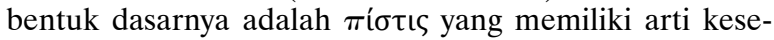
tiaan, keandalan, dan komitmen kepada Allah (BDAG,

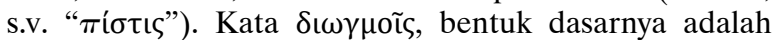
$\delta \iota \omega \gamma \mu$ ó $\varsigma$ yang memiliki arti penganiayaan atau sebuah rencana atau proses yang dirancang untuk menindas

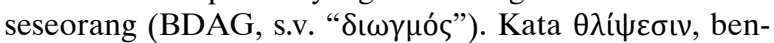
tuk dasarnya adalah $\theta \lambda \tilde{\imath} \psi \iota \varsigma$ yang memiliki arti penindasan, penderitaan, atau kesengsaraan yang disebabkan pihak luar (BDAG, s.v. " $\theta \lambda \tilde{u} \psi ı \varsigma ")$.

${ }^{46}$ Di dalam Kisah Para Rasul 17:8 dapat diketahui bahwa penganiayaan dan penindasan dilakukan oleh orang-orang Yahudi yang iri hati terhadap keberhasilan pengabaran Injil Paulus di kota Tesalonika.

${ }^{47}$ Robert A. Dooley dan Stephen H. Levinsohn, Analyzing Discourse: A Manual of Basic Concepts (Dallas: SIL International, 2001), 23-25; Witherington III, 1 and 2 Thessalonians, 191.

${ }^{48}$ Wallace, Greek Grammar, 414, 514.
}

terjadi dan dialami oleh jemaat Tesalonika. Dari segi lamanya waktu, penganiayaan dan penindas-an ini sudah berlangsung selama satu sampai dua tahun yaitu sejak Paulus datang pertama kali ke Tesalonika di tahun 49 sampai Paulus menulis surat 2 Tesalonika di tahun $50 .{ }^{49}$

Berdasarkan keterangan di atas dapat disimpulkan bahwa jemaat Tesalonika mengalami penganiayaan dan penindasan yang terus menerus. Perlu diperhatikan bahwa penganiayaan dan penindasan ini tidak melibatkan kematian fisik atau kemartiran tetapi melibatkan pelecehan sosial dan pengucilan. ${ }^{50}$

Kesimpulan dari bagian ini (ay. 3-4) adalah Paulus menyatakan betapa ia harus mengucap syukur kepada Allah karena iman jemaat Tesalonika yang terus menerus bertumbuh besar dan kasih jemaat yang terus menerus berkembang satu sama lain. Iman dan kasih jemaat Tesalonika ini juga yang membuat Paulus bermegah di antara jemaatjemaat Allah. Alasan lain Paulus bermegah di antara jemaat-jemaat Allah adalah karena ketabahan dan iman jemaat di tengah penganiayaan dan penindasan yang mereka sedang alami sejak satu atau dua tahun yang lalu. Sikap Paulus menyatakan mengucap syukur kepada Allah dan bermegah di antara jemaat-jemaat Allah tentu saja memberi penghiburan dan dorongan semangat kepada jemaat untuk terus memiliki iman, kasih dan ketabahan di tengah penganiayaan dan penindasan yang mereka alami. ${ }^{51}$

\section{Bagian Kedua (ay. 5-10)}

Bagian ini dimulai dengan kalimat $\varepsilon^{\prime} \delta \varepsilon \imath \gamma \mu \alpha$

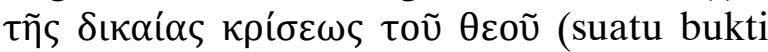
dari penghakiman Allah yang adil). Kata

${ }^{49}$ D.A. Carson dan Douglas J. Moo, Introducing the New Testament: A Short Guide to Its History and Message (Grand Rapids: Zondervan, 2010), 117.

${ }^{50}$ Weima, 1-2 Thessalonians, 457-58.

${ }^{51}$ Fee, Thessalonians, 247; Weima, 1-2 Thessalonians, 445 . 
$\varepsilon ̌ v \delta \varepsilon 1 \gamma \mu \alpha$ merupakan hapax legomenon di dalam Perjanjian Baru. Kata ini memiliki arti the proof of something, evidence, plain indication. ${ }^{52}$ Kata $\varepsilon v \delta \varepsilon \imath \gamma \mu \alpha$ memiliki sinonim dengan kata $\varepsilon^{\prime} v \delta \varepsilon 1 \xi_{1 \zeta}$ yang berarti sign, omen, demonstration, proof. ${ }^{53}$

Penulis berpendapat $\check{\varepsilon} v \delta \varepsilon \imath \gamma \mu \alpha$ merujuk ke ayat setelahnya sehingga bukti dari penghakiman Allah yang adil dijelaskan lebih lanjut di dalam ayat-ayat berikutnya (ay. 5$10)$. Kata $\varepsilon v \delta \varepsilon \imath \gamma \mu \alpha$ tidak dapat merujuk ke ayat sebelumnya yaitu ayat $3-4 .^{54}$

Rujukan ke ayat setelahnya ini didasarkan atas lima alasan, yaitu pertama terdapat asindeton yang berada di ayat 5a. Keberadaan asindeton di ayat 5 a memberi petunjuk adanya titik diskontinuitas yaitu adanya pemikiran atau topik baru. Hal ini dapat diperhatikan dari konteks ayat 3-4 yang berbicara mengenai ucapan syukur Paulus, sedangkan ayat 5-10 berbicara mengenai dua aspek penghakiman Allah yang adil yaitu pembalasan kepada orang yang tidak percaya dan upah bagi orang percaya.

\footnotetext{
${ }^{52}$ BDAG, s.v. "ع้ $v \delta \varepsilon \imath \gamma \mu \alpha . "$

${ }^{53}$ BDAG, s.v. “"̌v $\delta \varepsilon 1 \xi 1 \varsigma$.” Untuk penggunaan $\varepsilon ้ v \delta \varepsilon 1 \xi 1 \varsigma$ dapat dilihat di Flp. 1:28; Rm. 3:25; 2Kor. 8:24.

${ }^{54}$ Pendapat penulis ini sesuai dengan pemahaman dari Witherington III, 1 and 2 Thessalonians, 191-92; Weima, 1-2 Thessalonians, 461-62; Linda McKinnish Bridges, 1\&2 Thessalonians, Smyth \& Helwys Bible Commentary (Macon: Smyth \& Helwys Publishing, 2008), 219. Lihat juga pendapat dari para sarjana Perjanjian Baru yang memahami हैv $\delta \varepsilon \imath \gamma \mu \alpha$ ke ayat sebelumnya contohnya Gordon D. Fee, Leon Morris yang berpendapat bahwa bukti penghakiman Allah yang adil merujuk kepada ketabahan dan iman jemaat Tesalonika dalam menghadapi penganiayaan (ay. 4) (Leon Morris, The First and Second Epistles to the Thessalonians, ed. revisi., NICNT (Grand Rapids: Eerdmans, 1991), 197; Fee, Thessalonians, 253). Lihat juga pendapat dari Jouette M. Bassler, Wanamaker, Gene L. Green, dan Maarten J.J. Menken yang berpendapat bahwa bukti penghakiman Allah yang adil merujuk kepada semua penganiayaanpenganiayaan dan di dalam penindasan-penindasan yang kalian tanggung (ay. 4) (Jouette M. Bassler, "The Enigmatic Sign: 2 Thessalonians 1:5" The Catholic Biblical Quarterly 46, no. 3 (Juli 1984): 500; Wanamaker, Thessalonians, 221; Green, Thessalonians, 284; Maarten J.J. Menken, 2 Thessalonians (London: Routledge, 1994), $85)$.
}

Keberadaan asindeton yang terdapat di ayat 5a, 8b dan 9a juga memberi petunjuk adanya keterkaitan yang erat antara ayat 5-10 dan ayat 5-10 merupakan satu bagian besar yang menjelaskan mengenai bukti ( $\left.\varepsilon^{\prime} \delta \varepsilon \imath \gamma \mu \alpha\right)$ penghakiman Allah yang adil. Keterkaitan ini dapat diperhatikan melalui adanya hubungan proposisi dari generik ke spesifik dari ayat 5 ke 10.

Di ayat $8 b$ terdapat asindeton yang menjelaskan hubungan dari proposisi generik ke spesifik. Dari konteks ayat dapat diperhatikan bahwa proposisi spesifik yang ingin dijelaskan adalah pembalasan Allah yang terdapat di ayat 5a-8a diberikan juga kepada orang-orang yang tidak mengenal Allah dan kepada orang-orang yang tidak taat kepada berita Injil (ay. 8b-c). Untuk itu Paulus di bagian ini tidak membatasi pembalasan Allah hanya kepada penganiaya jemaat Tesalonika tetapi pembalasan akan diberikan juga kepada kelompok yang lebih besar. Tujuan Paulus adalah untuk menjelaskan bahwa semua orang akan dibalas secara adil karena mereka gagal untuk mengenal Allah dan menaati Injil..$^{55}$

Di dalam ayat $9 \mathrm{~b}$ terdapat asindeton yang menjelaskan hubungan dari proposisi generik ke spesifik. Dari konteks ayat dapat diperhatikan bahwa proposisi spesifik yang ingin dijelaskan adalah orang yang tidak mengenal Allah dan yang tidak taat kepada berita Injil yang terdapat di ayat $8 \mathrm{~b}-\mathrm{c}$ akan menerima hukuman pada hari Tuhan yaitu berupa kehancuran kekal, jauh dari kehadiran Allah dan jauh dari kemuliaan-Nya sedangkan orang yang bersikap sebaliknya yaitu jemaat Tesalonika yang mau menerima berita Injil akan menerima kemuliaan dan keagungan (9a). Hal ini akan terjadi pada saat Yesus Kristus datang untuk kedua kalinya (ay. 10).

${ }^{55}$ Weima, 1-2 Thessalonians, 473; Wanamaker, Thessalonians, 227. 
Kedua, terdapat perbedaan isi teks. Perbedaan isi teks ini dapat dilihat dari ayat 3-4 yang berfokus kepada keadaan masa kini di mana jemaat Tesalonika mengalami penganiayaan dan penindasan, sedangkan ayat 510 berfokus kepada aspek eskatologi penghakiman Allah yang adil yang akan terjadi di masa depan. ${ }^{56}$

Ketiga, terdapat perbedaan dalam hal tindakan. Ayat 3-4 berfokus kepada tindakan manusia yaitu pertumbuhan rohani jemaat Tesalonika dalam menghadapi penganiayaan, sedangkan ayat 5-10 berfokus kepada tindakan penghakiman Allah yang adil yang akan memberi hukuman kepada para penindas dan upah kepada orang percaya. ${ }^{57}$

Keempat, terdapat perbedaan dalam hal sastra. Akar kata $\delta$ ík yang berarti adil atau keadilan tidak muncul di ayat 3-4 tetapi muncul sebanyak empat kali di ayat 5-10 yaitu

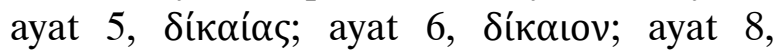

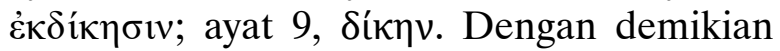
ayat 5-10 merupakan satu bagian yang memiliki keterkaitan koherensi leksikal. ${ }^{58}$ Koherensi ini bermanfaat supaya pembaca surat 2 Tesalonika dapat membangun sebuah penggambaran mental sehingga pada akhirnya mereka dapat memahami dengan jelas apa yang dimaksud Paulus yaitu penghakiman Allah yang adil. ${ }^{59}$

Kelima, pemahaman bahwa bukti penghakiman Allah yang adil merujuk ke ayat setelahnya dijelaskan dengan keberadaan protasis dan apodosis. Keberadaan protasis terdapat di ayat 6-10 yang dimulai dengan ka-

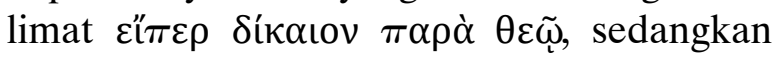
keberadaan apodosis terdapat di ayat 5 yaitu

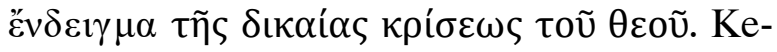
beradaan protasis dan apodosis ini membentuk kesatuan kalimat yang ada di ayat 5-10. ${ }^{60}$

\footnotetext{
${ }^{56}$ Weima, 1-2 Thessalonians, 443.

${ }^{57} \mathrm{Ibid}$.

${ }^{58}$ Ibid.; Bridges, $1 \& 2$ Thessalonians, 219.

${ }^{59}$ Dooley dan Levinsohn, Analyzing Discourse, 23-24.

${ }^{60}$ Weima, 1-2 Thessalonians, 462, 64.
}

Berdasarkan penjelasan di atas yang merujuk $\varepsilon \vee \delta \delta \varepsilon 1 \gamma \mu \alpha$ ke ayat setelahnya maka penulis berpendapat bahwa sebelum kata $\check{\varepsilon} v \delta \varepsilon 1 \gamma \mu \alpha$

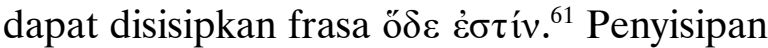

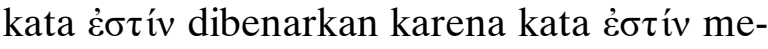
rupakan kata yang paling sering dihilangkan. ${ }^{62}$ Sedangkan kata ö $\delta \varepsilon$ merupakan artikel referensi atas apa yang akan mendahului dan memiliki arti "ini". ${ }^{63}$ Penyisipan klausa ő $\delta \varepsilon$ $\dot{\varepsilon} \sigma \tau i ́ v$ menjadikan $\tilde{\varepsilon} v \delta \varepsilon \imath \gamma \mu \alpha$ berbentuk nomina, nominatif, tunggal, netral.

Setelah penulis memberikan penjelasan mengenai $\varepsilon^{\prime} \delta \delta \varepsilon \imath \mu \alpha$ merujuk ke ayat setelahnya. Di bawah ini akan dipaparkan lebih lanjut pembahasan ayat 6-10. Di dalam ayat 6-10 terdapat dua aspek dari penghakiman Allah yang adil yaitu pembalasan kepada penindas dan upah kepada orang percaya. Aspek pertama dari penghakiman Allah yang adil adalah pembalasan kepada para penindas. Pau-

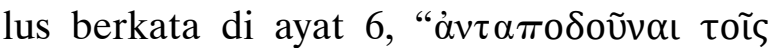
$\theta \lambda i ́ \beta o v \sigma ı v$ v $\mu \tilde{\alpha} \varsigma \theta \lambda \tilde{\imath} \psi ı v "$ (membalaskan kepada orang-orang yang menindas kalian dengan penindasan). Kata $\alpha \dot{\nu} \tau \alpha \pi$ o $\delta i ́ \delta \omega \mu$ (kata

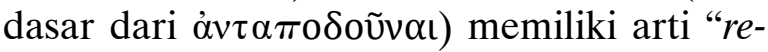
pay, pay back" dan memiliki ide pembalasan yaitu bagaimana Allah akan membalas kepada musuh-musuh-Nya pada hari penghakiman terakhir. ${ }^{64}$

Ide pembalasan merupakan prinsip yang telah ada di Perjanjian Lama yang dikenal dengan prinsip lex talionis. Prinsip ini berkata, "mata ganti mata, gigi ganti gigi, tangan ganti tangan, kaki ganti kaki, lecur ganti lecur, luka ganti luka, bengkak ganti bengkak" (Kel. 21:24-25).

Ide pembalasan ini juga menggemakan perkataan Allah di Yesaya 66. Di ayat 6b, Allah

\footnotetext{
${ }^{61}$ Witherington III, 1 and 2 Thessalonians, 192; Weima, 1-2 Thessalonians, 461.

${ }^{62} \mathrm{BDF}, \$ 127$

${ }^{63}$ BDAG, s.v. "ő $\delta \varepsilon . "$

${ }^{64} \mathrm{BDAG}$, s.v. " $\dot{\alpha} v \tau \alpha \pi \mathrm{o} \delta \dot{i} \delta \omega \mu \mathrm{i} ; ”$ Matthew D. Aernie, Forensic Language and the Day of the Lord Motif in Second Thessalonians 1 and the Effects on the Meaning of the Text (Eugene: Wipf and Stock, 2011), 91.
} 
berkata, "Dengar, TUHAN melakukan pembalasan kepada musuh-musuh-Nya!" Di dalam LXX kata pembalasan menggunakan

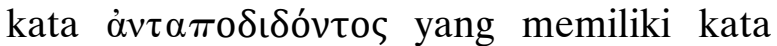
dasar $\dot{\alpha} v \tau \alpha \pi$ o $\delta i ́ \delta \omega \mu$, kata dasar yang sama digunakan di ayat $6 .{ }^{65}$

Pembalasan Allah ini adalah berupa $\theta \lambda \tilde{\imath} \psi \iota \varsigma$ (penindasan), kata yang sama yang dipakai Paulus di ayat 4 untuk menjelaskan penindasan yang sedang dialami oleh jemaat Tesalonika. Paulus dengan menggunakan kata yang sama hendak menjelaskan bahwa para penindas itu akan mendapatkan penindasan yang sama seperti yang jemaat Tesalonika alami saat ini. Tujuan Paulus menggunakan prinsip Perjanjian Lama dan menggunakan kata yang sama adalah untuk menghibur jemaat Tesalonika yang saat ini mengalami penindasan dengan mengingatkan mereka akan penghakiman Allah di masa depan sebagai waktu ketika penindasan mereka akan dibalas. ${ }^{66}$

Aspek kedua dari penghakiman Allah yang adil adalah upah kepada orang percaya.

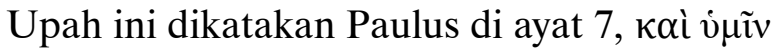

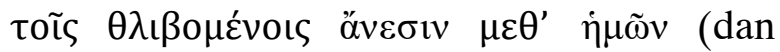
kepada kalian yang ditindas dengan kelegaan bersama kami). Terdapat empat hal yang perlu diperhatikan dalam bagian ini

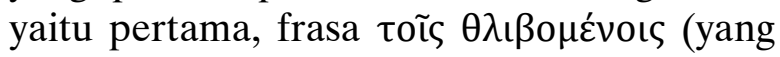
ditindas) berbentuk kala sekarang yang memiliki arti bahwa penindasan merupakan kondisi yang terjadi di masa kini. Kedua, ka-

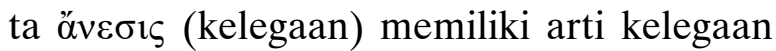
atau istirahat dari suatu hal yang memberatkan atau menyusahkan dari penganiayaan dan penindasan yang dilakukan oleh orangorang yang tidak percaya. ${ }^{67}$ Perlu dipahami bahwa kelegaan tidak hanya dialami oleh jemaat Tesalonika tetapi juga dialami $\mu \varepsilon \theta$ '

${ }^{65}$ Jeffrey A.D. Weima, "1-2 Thessalonians," dalam Commentary on the New Testament Use of the Old Testament, ed. G.K. Beale dan D.A Carson (Grand Rapids: Baker Academic, 2007), 883.

${ }^{66}$ Ibid.

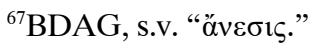

$\dot{\eta} \mu \tilde{\omega} v$ (bersama kami), yaitu dialami juga oleh Paulus, Silwanus dan Timotius serta semua orang yang percaya kepada Yesus Kris-

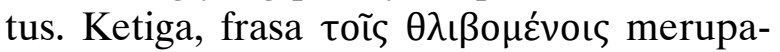

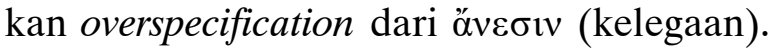
Adanya overspecification ini memberi informasi tambahan bahwa kelegaan akan diberikan kepada jemaat Tesalonika yang sedang ditindas dan kelegaan merupakan bagian dari tema penghakiman Allah yang adil. Keempat, kelegaan ini terjadi ketika $\dot{\alpha} \pi 0 \kappa \alpha \lambda u ́ \psi \varepsilon \iota$

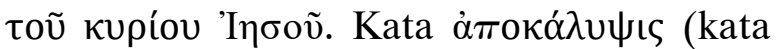
dasar dari $\dot{\alpha} \pi$ oк $\alpha \lambda u ́ \psi \varepsilon \iota)$ memiliki arti pengungkapan yang akan terjadi di hari-hari terakhir. $^{68}$ Untuk itu kelegaan tidak berupa berhentinya penganiayaan di masa kini tetapi bersifat eskatologi yaitu terjadi di masa depan ketika Yesus Kristus datang kedua kali. ${ }^{69}$ Paulus berkata bahwa pada saat penampakan Yesus Kristus akan bersamasama dengan malaikat-malaikat-Nya yang berkuasa dalam api yang menyala-nyala. Ini artinya kedatangan Yesus kedua kali akan disertai dengan pengungkapan Yesus Kristus ke seluruh dunia bahwa Yesus adalah mulia dan berkuasa. ${ }^{70}$

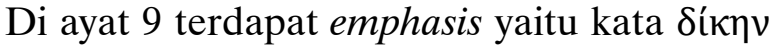

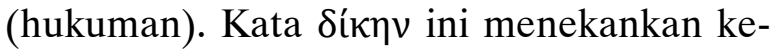
beradaan penghukuman Allah yang berupa kehancuran kekal, jauh dari hadirat Allah dan jauh dari kemuliaan kekuatan-Nya.

Di ayat 10a terdapat far distinction yaitu kata

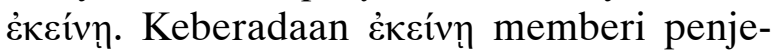
lasan adanya elemen yang secara ruang dan waktu terjadi jauh dari konteks saat ini. Da-

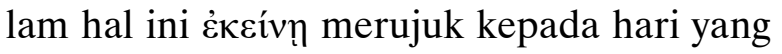
akan terjadi di masa depan di mana Yesus datang untuk dimuliakan di antara orangorang kudus-Nya dan diagungkan di antara semua orang-orang percaya (ay. 10).

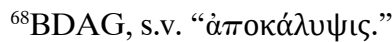

${ }^{69}$ Weima, 1-2 Thessalonians, 467; Witherington III, 1 and 2 Thessalonians, 194.

${ }^{70}$ George E. Ladd, A Theology of the New Testament, ed. Donald A. Hagner, ed. revisi (Grand Rapids: Eerdmans, 1993), 601.
} 
Frasa "hari itu" dijelaskan Paulus lebih lanjut di 2 Tesalonika 2:2. Di ayat ini "hari itu" merupakan "hari Tuhan" yang merupakan hari di mana Tuhan Yesus datang dan penghakiman Allah yang adil akan dilaksanakan. ${ }^{71}$ Di dalam Perjanjian Lama, kedatangan hari Tuhan ini dikatakan oleh para nabi, yaitu nabi Yesaya (Yes. 2; 66), nabi Amos (Am. 2; 5; 8), dan nabi Yeremia (Yer. 20; 25).

Di ayat 9a-b terdapat right dislocation. Da-

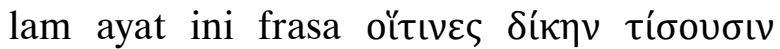
(mereka akan menerima pembalasan) dijelaskan lebih lanjut dengan penempatan right

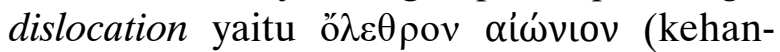

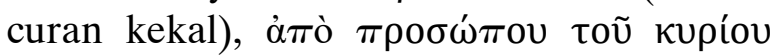
(jauh dari kehadiran Allah), dan $\alpha \pi$ ò $\tau \tilde{\eta} \varsigma$

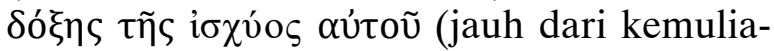
an kekuatan-Nya) (ay. 9a-10b). Penempatan right dislocation memberi informasi tambahan bahwa penghukuman yang akan diberikan Allah adalah berupa kehancuran kekal, jauh dari kehadiran Allah, dan jauh dari kemuliaan kekuatan-Nya.

Perlu diperhatikan bahwa kata ö $\lambda \varepsilon \theta \rho o v(k a-$ ta dasarnya adalah ő $\lambda \varepsilon \theta \rho \circ \varsigma$ ) berarti kehancuran secara fisik dan arti metafora yaitu bencana, ${ }^{72}$ sedangkan kata sifat $\alpha i ́ \omega$ vıov berarti suatu periode waktu yang tidak memiliki

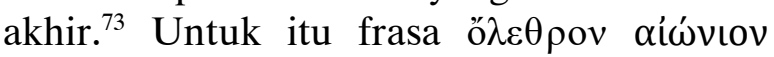
berarti suatu kehancuran yang tidak pernah berakhir dan bukan suatu anihilasi. ${ }^{74}$ Se-

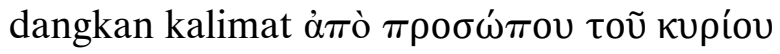

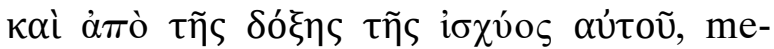
miliki arti pemisahan, yaitu mereka akan dipisahkan dari kehadiran Tuhan Yesus yang mulia dan berkuasa, dan ini merupakan pembalikan karena jemaat Tesalonika akan

\footnotetext{
${ }^{71}$ Bruce, 1 and 2 Thessalonians, 153; Weima, 1-2 Thessalonians, 479.

${ }^{72} \mathrm{BDAG}, \mathrm{s.v.}$ "ő $\lambda \varepsilon \theta \rho \circ \varsigma$ ”; Weima, 1-2 Thessalonians, 474.

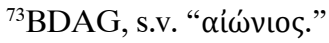

${ }^{74}$ G.K. Beale, 1-2 Thessalonians, IVPNTC (Downers Grove: InterVarsity, 2003), 188-89; Weima, 1-2 Thessalonians, 474; Gary S. Shogren, 1 and 2 Thessalonians, ZECNT (Grand Rapids: Zondervan, 2012), 252.
}

berada di dalam hadirat Tuhan (2Tes. $5: 10) .{ }^{75}$

Setelah menyatakan pembalasan Allah maka Paulus menyatakan bahwa jemaat Tesalonika akan menerima upah. Dalam hal ini jemaat Tesalonika akan $\dot{\varepsilon} v \delta o \xi \alpha \sigma \theta \tilde{\eta} v \alpha \iota$ (dimuliakan) dan $\theta \alpha v \mu \alpha \sigma \theta \tilde{\eta} v \alpha$ ( (diagungkan) ketika Yesus datang pada hari itu (ay. 10). Pada hari itu Allah memberikan upah kepada jemaat Tesalonika yaitu mereka dimuliakan dan diagungkan. Upah ini menjadi suatu kontras dengan hukuman yang diberikan kepada orang-orang yang tidak percaya yaitu kehancuran kekal, jauh dari kehadiran Allah dan jauh dari kemuliaan kekuatan-Nya. ${ }^{76}$

Paulus menuliskan kata ö ı (ay. 10c) yang merupakan kata penghubung dan penanda kausalitas mengapa jemaat Tesalonika dimuliakan dan diagungkan. Bagi Paulus, jemaat Tesalonika dimuliakan dan diagungkan karena kesaksian Paulus, Silwanus dan Timotius telah dipercaya oleh jemaat Tesalonika. Kesaksian ini berupa kesaksian akan kematian dan kebangkitan Yesus Kristus. ${ }^{77}$

Kesimpulan dari bagian ini adalah Paulus menyatakan bahwa bukti penghakiman Allah yang adil merujuk ke ayat setelahnya yaitu ayat 6-10. Penghakiman Allah yang adil ini berupa pembalasan kepada para penindas dan upah kepada orang percaya. Penghakiman Allah yang adil ini akan terjadi di masa depan ketika Yesus Kristus datang untuk kedua kali.

\section{KESIMPULAN}

Makalah ini telah memaparkan mengenai penghakiman Allah yang adil di dalam 2 Tesalonika 1:3-10 menurut pendekatan AW.

\footnotetext{
${ }^{75}$ Weima, 1-2 Thessalonians, 475; Bridges, $1 \& 2$ Thessalonians, 221.

${ }^{76}$ Weima, 1-2 Thessalonians, 476; Witherington III, 1 and 2 Thessalonians, 196.

${ }^{77}$ Weima, 1-2 Thessalonians, 478; Bruce, 1 and 2 Thessalonians, 153.
} 
Melalui pendekatan AW dapat diperhatikan bahwa perikop 2 Tesalonika 1:3-10 terdiri dari dua bagian yaitu bagian pertama (ay. 34) dan bagian kedua (ay. 5-10). Bagian pertama berbicara mengenai ucapan syukur Paulus kepada Allah karena iman dan kasih jemaat Tesalonika yang berkembang dan bertumbuh di dalam penganiayaan dan penindasan. Keberadaan jemaat Tesalonika yang tetap tabah dan beriman juga menjadi dasar bagi Paulus untuk bermegah di antara jemaat-jemaat Allah yang lain. Bagian kedua berbicara mengenai bukti penghakiman Allah yang adil.

Melalui pendekatan AW dapat diperhatikan bahwa bukti penghakiman Allah yang adil ini merujuk ke ayat setelahnya dan bukan ke ayat sebelumnya. Penghakiman Allah ini terdiri dari dua aspek yaitu pembalasan Allah kepada para penindas dan upah kepada jemaat Tesalonika. Penghakiman ini akan terjadi di masa depan.

Pemaparan Paulus di atas tentunya memberi penghiburan dan kekuatan kepada jemaat Tesalonika dan kepada jemaat Kristen di masa kini bahwa penganiayaan dan penindasan tidak pernah terlepas dari penghakiman Allah yang adil. Allah yang adil akan menghakimi setiap orang dengan memberi pembalasan kepada para penindas dan upah kepada setiap orang yang tetap setia kepada Yesus Kristus.

\section{DAFTAR KEPUSTAKAAN}

Aernie, Matthew D. Forensic Language and the Day of the Lord Motif in Second Thessalonians 1 and the Effects on the Meaning of the Text. Eugene: Wipf and Stock, 2011.

Bauer, Walter, Frederick W. Danker, William F. Arndt, dan F. Wilbur Gingrich. A Greek-English Lexicon of the New Testament and Other Early Christian Literature. Ed. ke-3. Chicago: University of Chicago, 2000.
Bassler, Jouette M. "The Enigmatic Sign: 2 Thessalonians 1:5" The Catholic Biblical Quarterly 46, no. 3 (Juli 1984): 496510.

Beale, G.K. 1-2 Thessalonians. IVPNTC. Downers Grove: InterVarsity, 2003.

Best, Ernest. The First and Second Epistles to the Thessalonians. BNTC. Peabody: Hendrickson, 1972.

Blass, Friedrich, dan Albert Debrunner. $A$ Greek Grammar of the New Testament and Other Early Christian Literature. Diterjemahkan oleh Robert W. Funk. Chicago: University of Chicago, 1961.

Bridges, Linda McKinnish. 1 \& 2 Thessalonians. Smyth \& Helwys Bible Commentary. Macon: Smyth \& Helwys Publishing, 2008.

Brown, Raymond E. An Introduction to the New Testament. New York: Doubleday, 1997.

Bruce, F. F. 1 and 2 Thessalonians. WBC 45. Dallas: Word, 2002.

Campbell, Constantine R. Advances in the Study of Greek. Grand Rapids: Zondervan, 2015.

Carson, D.A., dan Douglas J. Moo. An Introduction to the New Testament. Ed. ke-2. Grand Rapids: Zondervan, 2005.

- Introducing the New Testament: A Short Guide to Its History and Message. Grand Rapids: Zondervan, 2010.

Donfried, Karl P., dan I. Howard Marshall. The Theology of the Shorter Pauline Letters. Cambridge: Cambridge University Press, 1993.

Dooley, Robert A., dan Stephen H. Levinsohn. Analyzing Discourse: A Manual of Basic Concepts. Dallas: SIL Interna-tional, 2001.

Ellingworth, Paul, dan Eugene A. Nida. Surat-Surat Paulus Kepada Jemaat di Tesalonika. Diterjemahkan oleh Kareasi H. Tambur dan Anwar Tjen. Pedoman Penafsiran Alkitab. Jakarta: LAI, 2001.

Fee, Gordon D. The First and Second Letters to the Thessalonians. NICNT. Grand 
Rapids: Eerdmans, 2009.

Green, Gene L. The Letters to the Thessalonians. PNTC. Grand Rapids: Eerdmans, 2002.

Guthrie, Donald. New Testament Introduction. Ed. ke-4. Downers Grove: InterVarsity, 1990.

Halliday, M.A.K. An Introduction to Functional Grammar. London: Edwin Arnold, 1995.

Ladd, George E. A Theology of the New Testament. Diedit oleh Donald A. Hagner. Ed. revisi. Grand Rapids: Eerdmans, 1993.

Levinsohn, Stephen H. Discourse Features of New Testament Greek. Ed. ke-2. Dallas: SIL International, 2000.

Louw, Johannes P. Semantics of New Testament Greek. Philadelphia: Fortress, 1982.

Malherbe, Abraham J. The Letters to the Thessalonians. AYB. New Haven: Yale, 2008.

Martin, D. Michael. 1, 2 Thessalonians. NAC 33. Nashville: Broadman \& Holman, 1995.

Menken, Maarten J.J. 2 Thessalonians. London: Routledge, 1994.

Morris, Leon. 1 and 2 Thessalonians. Vol. 13. TNTC. Downers Grove: InterVarsity, 1984.

- The First and Second Epistles to the Thessalonians. Ed. revisi. NICNT. Grand Rapids: Eerdmans, 1991.
Mounce, William D. Basics of Biblical Greek Grammar. Ed. ke-4. Grand Rapids: Zondervan, 2019.

Porter, Stanley E. "Discourse Analysis and New Testament Studies: An Introductory Survey." Dalam Discourse Analysis and Other Topics in Biblical Greek, diedit oleh Stanley E. Porter dan D.A. Carson. JSNTS 113. Sheffield: Sheffield Academic, 1995.

Runge, Steven E. Discourse Grammar of the Greek New Testament. Peabody: Hendrickson, 2010.

- The Lexham Discourse Greek New Testament. Bellingham: Logos Research Systems, 2008.

Shogren, Gary S. 1 and 2 Thessalonians. ZECNT. Grand Rapids: Zondervan, 2012.

Wallace, Daniel B. Greek Grammar Beyond the Basics. Grand Rapids: Zondervan, 1996.

Wanamaker, Charles A. The Epistles to the Thessalonians. NIGTC. Grand Rapids: Eerdmans, 1990.

Weima, Jeffrey A.D. "1-2 Thessalonians." Dalam Commentary on the New Testament Use of the Old Testament, diedit oleh G.K. Beale dan D.A. Carson. Grand Rapids: Baker Academic, 2007.

- 1-2 Thessalonians. BECNT. Grand Rapids: Baker Academic, 2014.

Witherington III, Ben. 1 and 2 Thessalonians. Grand Rapids: Eerdmans, 2006. 